\title{
Isolation of Cronobacter spp. (formerly Enterobacter sakazakii) from infant food, herbs and environmental samples and the subsequent identification and confirmation of the isolates using biochemical, chromogenic assays, PCR and I6S rRNA sequencing Ziad W Jaradat*†, Qotaiba O Ababneh ${ }^{\dagger}$, Ismail M Saadoun, Nawal A Samara and Abrar M Rashdan
}

Address: Department of Biotechnology and Genetic Engineering, Jordan University of Science and Technology, P. O. Box 3030, Irbid-22110, Jordan

Email: Ziad W Jaradat* - jaradatz@just.edu.jo; Qotaiba O Ababneh - qoia_16@yahoo.com; Ismail M Saadoun - isaadoun@just.edu.jo; Nawal A Samara - nawal_samarah@yahoo.com; Abrar M Rashdan - rashdan_abrar@yahoo.com

* Corresponding author †Equal contributors

Published: 27 October 2009

BMC Microbiology 2009, 9:225 doi:10.1 I86/147I-2180-9-225
Received: 10 March 2009

Accepted: 27 October 2009

This article is available from: http://www.biomedcentral.com//47/-2/80/9/225

(c) 2009 Jaradat et al; licensee BioMed Central Ltd.

This is an Open Access article distributed under the terms of the Creative Commons Attribution License (http://creativecommons.org/licenses/by/2.0), which permits unrestricted use, distribution, and reproduction in any medium, provided the original work is properly cited.

\begin{abstract}
Background: Cronobacter spp. (formerly Enterobacter sakazakii), are a group of Gram-negative pathogens that have been implicated as causative agents of meningitis and necrotizing enterocolitis in infants. The pathogens are linked to infant formula; however, they have also been isolated from a wide range of foods and environmental samples.
\end{abstract}

Results: In this study, 233 samples of food, infant formula and environment were screened for the presence of Cronobacter spp. in an attempt to find its source. Twenty nine strains were isolated from samples of spices, herbs, infant foods, and dust obtained from household vacuum cleaners. Among the 76 samples of infant food, infant formula, milk powder and non-milk dairy products tested, only one sample of infant food contained Cronobacter spp. ( $1.4 \%$ ). The other Cronobacter spp. isolates recovered include two from household vacuum dust, and 26 from 67 samples of herbs and spices. Among the food categories analyzed, herbs and spices harbored the highest number of isolates, indicating plants as a possible reservoir of this pathogen. Initial screening with API 20E test strips yielded 42 presumptive isolates. Further characterization using 3 chromogenic media $(\alpha-$ MUG, DFI and EsPM) and 8 sets of PCR primers detecting ITS (internal transcribed spacer sequences), $16 \mathrm{~S}$ rRNA, zpx, gluA, gluB, OmpA genes followed by nucleotide sequencing of some PCR amplicons did not confirm the identity of all the isolates as none of the methods proved to be free of both false positives or false negatives. The final confirmation step was done by $16 \mathrm{~S}$ rRNA sequence analysis identifying only 29 of the 42 isolates as Cronobacter spp.

Conclusion: Our studies showed that Cronobacter spp. are highly diverse and share many phenotypic traits with other Enterobacteriaceae members highlighting the need to use several methods to confirm the identity of this pathogen. None of the biochemical, chromogenic or PCR primers proved to be a reliable method for confirmation of the identity of the isolates as all of them gave either false positives or false negatives or both. It is therefore concluded that I6S rRNA sequencing is pivotal to confirm the identity of the isolates. 


\section{Background}

Cronobacter spp. (formerly Enterobacter sakazakii), a member of the Enterobacteriaceae family, are motile, non spore forming, Gram-negative facultative anaerobes. They are catalase positive, oxidase negative, and generally positive for $\alpha$-D-glucosidase [1-4]. Cronobacter spp. have been repeatedly reported as remarkably resistant to osmotic stress and dryness and moderately thermotolerant as some encapsulated Cronobacter spp. were still recoverable from desiccated infant formula after storage for up to 2.5 years [5-7]. The composition of dry foods and infant formula combined with their low aw (ca. 0.2) significantly affected the survival of Cronobacter spp. in these foods $[6,8,9]$.

Cronobacter spp. cause meningitis and necrotizing enterocolitis in infants, and septicemia and catheter-associated infections in elderly and immunocompromised people, with mortality rates ranging between 10 to $80 \%$ [10-17]. Among the cases, about half of the patients died within one week of the onset of the infections and about $94 \%$ of the meningitis survivors exhibited severe neurological complications $[12,14,18]$.

Infant formula has been associated with severe systemic neonatal infections by Cronobacter spp., and thus these organisms are considered to be infant formula pathogens [11]. Nonetheless, Cronobacter spp. have been isolated from a wide range of habitats which include milk powder, formula constituents and from environments from within manufacturing plants [19-22], and household utensils such as blenders, infant bottle cleaning brushes and spoons [23-26]. Furthermore, they have been isolated from different types of foods such as rice, cured meat, sausages and minced meat, acidic sobia (a fermented beverage with pH range $3.4-5.5$ ), soured tea, lettuce, and other vegetables [27-31]. In humans, it has been isolated from cerebrospinal fluid, blood, skin wounds, breast abscess, urine, respiratory secretions and digestive tract samples $[10,32,33]$. In addition to food and clinical samples, Cronobacter spp. were isolated from various insect's intestinal tracts such as the Mexican fruit fly Anastrepha ludens and the stable fly Stomoxys calcitrans. They have also been isolated from rats, soil sediment, wetland, and even crude oil [34-39].

Cronobacter spp. was defined as a new species by Farmer et al. [19], before which, it was known as "yellow pigmented Enterobacter cloacae." It produces yellow pigmented colonies on trypticase soy agar (TSA), after 48-72 h [1]. However, the production of the yellow pigment is not exclusive for Cronobacter spp. as other organisms also produce yellow-colored colonies on TSA. In addition, it was found that not all Cronobacter spp. produces yellow color on TSA [2]. In a previous study, Farmer et al., [19] grouped 57 strains of E. sakazakii into 15 biogroups which later, Iversen et al., [40] expanded by using cluster analysis (based on partial 16S rRNA sequence analysis) of 189 strains to include a $16^{\text {th }}$ biogroup. This was followed by two proposals by Iversen et al. [41,42] showing that this organism comprised of six related groups of strains that could be separated on the basis of DNA-DNA hybridization relatedness and phenotypic traits, into 5 novel species and 1 novel genomospecies within a new genus named Cronobacter. These studies gave a clear indication of the genetic and phenotypic heterogeneity among these organisms. Therefore, it is important that the presence and the identity of Cronobacter spp. be confirmed by more than one method. Biochemical, chromogenic and molecular techniques such as PCR that amplify specific Cronobacter spp. genes and 16S rRNA sequencing analysis should be among the methods used for this purpose. The aims of this study therefore were to analyze a wide range of foods including infant foods, milk powder, herbs, and environmental samples in an attempt to find the reservoir for this pathogen and to compare the biochemical, cultural and molecular methods for the proper identification and confirmation of Cronobacter spp.

\section{Methods \\ Samples collection}

A total of 222 samples of food, infant formula, infant foods, herbs and spices originating from 14 different countries were purchased from local markets. In addition, 11 environmental samples (vacuum dust and soil) were collected and tested for the presence of Cronobacter spp.

\section{Isolation of Cronobacter spp}

It is noteworthy to mention that in this study two methods of Cronobacter spp. isolation were used. The FDA method [43] was used at the beginning of the project for the isolation of Cronobacter spp. from the food and herbal samples. However, during the project, a new modified method for the isolation of Cronobacter spp. was developed [2]. Thus, the new method was adopted for the isolation of Cronobacter spp. from infant formula and milk powder samples.

\section{Isolation of Cronobacter spp. from infant formula, milk powder and infant foods}

A total of 76 samples (40 infant formulas and solid infant foods, 29 milk powder and 7 dairy non-milk foods) were tested for the presence of Cronobacter spp. using the method described by Iversen and Forsythe, [2]. Briefly, $100 \mathrm{~g}$ of infant food, milk powder or infant formula were added to $900 \mathrm{ml}$ of peptone water and warmed up for 25 min at $45^{\circ} \mathrm{C}$. Ten milliliters were then incubated in $E$. sakazakii enrichment broth (ESE) for $24 \mathrm{~h}$ at $37^{\circ} \mathrm{C}$. From each enriched sample, $0.1 \mathrm{ml}$ and $1 \mathrm{ml}$ were streaked or spread onto Druggan Forsythe Iversen (DFI, Oxoid, UK, ) 
agar and incubated for $24 \mathrm{~h}$ at $37^{\circ} \mathrm{C}$. Green/bluish colonies were considered presumptive Cronobacter spp. and were subjected to further biochemical and molecular confirmation techniques.

\section{Isolation of Cronobacter spp. from food, herbs andenvironmental samples}

Cronobacter spp. were isolated from different food and herbal samples according to the FDA method [43] with modification. Briefly, $100 \mathrm{~g}$ of each sample were mixed thoroughly with $900 \mathrm{ml}$ of pre-warmed sterile distilled water at $45^{\circ} \mathrm{C}$, and incubated for $15-20 \mathrm{~min}$ in a water bath at the same temperature. Ten milliliters of each mixture were resuspended in $90 \mathrm{ml}$ of Enterobacteriaceae enrichment broth (EE, HighMedia, India) and incubated overnight at $37^{\circ} \mathrm{C}$. A loop full of the culture broth was streaked onto Violet Red Bile Glucose Agar (VRBGA, HighMedia, India) and another $0.1 \mathrm{ml}$ of the same culture was spread onto VRBGA agar plates and incubated for 20$24 \mathrm{~h}$ at $37^{\circ} \mathrm{C}$. All colonies were streaked onto tryptic soy agar (TSA) and incubated for $24-48 \mathrm{~h}$ at $37^{\circ} \mathrm{C}$ to look for the characteristic yellow colonies of Cronobacter spp. All colonies that appeared yellow on TSA were picked and subjected to further characterization using biochemical, chromogenic, PCR and 16S rRNA sequencing analysis. Confirmed cultures were preserved in EE broth containing $20 \%$ glycerol and stored at $-80^{\circ} \mathrm{C}$ for further studies.

\section{Biochemical characterization by API 20 E test strips}

Presumptive identification of oxidase-negative yellow colonies was performed by API 20E (Remel and/or BioMerieux, USA) biochemical profiling test according to manufacturer's instructions.

\section{Chromogenic assays for environmental isolates}

API 20E Cronobacter spp. positive isolates were streaked onto nutrient agar containing 4-methyl-umbelliferyl $\alpha$-Dglucoside ( $\alpha$-MUG, Oxoid, UK, ) a substrate which upon being metabolized forms yellow colonies that fluoresce under UV light. The same isolates were then further confirmed by streaking onto DFI chromogenic agar containing 5-bromo-4-chloro-3-indolyl- $\alpha$, D-glucopyranoside (XaGlc, Oxoid, UK, ) which upon hydrolysis of the substrate gives blue/green colonies typical for Cronobacter spp. Further, the presumptive isolates were inoculated onto the EsPM chromogenic medium (R \& F Laboratories, Downers Grove, IL) on which typical Cronobacter spp. colonies appeared blue/black as described by Restaino et al. [21].

\section{Molecular confirmation of the isolates using PCR and sequencing}

Eight sets of Cronobacter spp.-specific primers were used in the study and are listed in Table 1. Primers SG-F/SG-R and SI-F/SI-R, originally described by Liu et al. [44], were deduced from alignment of the internal transcribed spacer sequences. Primers Saka 1a -F/Saka 2b-R described by Hassan et al. [45] were deduced from variable region of the 16S rRNA gene. Primers ESSF/ESSR described by Nair and Venkitanarayanan [46] were deduced from the OmpA gene. Two primer sets reported by Kothary et al. [13] were deduced from the $z p x$ gene. Lastly, PCR primers reported by Lehner et al. $[3,47]$ were deduced from the $\alpha$-glucosidase genes, gluA and gluB (ORFs 71, 72) sequences. Reactions using primers Saka1a-F/Saka2b-R and SG-F/SG-R and SI-F/SI-R and ESSF/ESSR were optimized in a $50 \mu \mathrm{l}$ reaction mixture consisting of $5 \mu \mathrm{l}$ of the bacterial genomic DNA solution (50 ng), $3 \mathrm{mM} \mathrm{MgCl}, 0.25 \mu \mathrm{M}$ (each) dATP, dCTP, dTTP and dGTP; 2 U Taq DNA polymerase, $1.25 \mu \mathrm{l}(0.25 \mu \mathrm{M}$ each $)$ primers and $33.1 \mu \mathrm{l}$ nuclease free water. PCR products were analyzed using $2 \%$ $(\mathrm{w} / \mathrm{v})$ agarose gel electrophoreses in $0.5 \times$ TBE buffer and a constant voltage of $90 \mathrm{~V}$ to confirm the presence of amplified DNA. PCR assays using primers for $z p x$ and $g l u A / g l u B$ were according to parameters and conditions reported by the authors who originally described each PCR assay. For BAM primers (350 bp product), initially the PCR analysis was performed on all of the strains using reaction that used the $62^{\circ} \mathrm{C}$ annealing temperature. However, eight of the strains produced multiple bands in addition to the $350 \mathrm{bp}$ amplicon. Gradient PCR analysis of these strains was performed to find the best annealing temperature that give only one band (unpublished data). From this analysis, an annealing temperature of $50.5^{\circ} \mathrm{C}$ was selected to complete the study. Surprisingly, the lower annealing temperature gave one band which upon DNA sequencing appeared to be the correct one while the other non-specific bands disappeared. This unexpected result might be due to the use of the Invitrogen Platinum PCR super mix that was used at $50.5^{\circ} \mathrm{C}$ but not at other temperatures.

\section{DNA sequencing}

All products for nucleotide sequencing including the desalted PCR amplicons were obtained by using a QIAquick PCR Purification Kit according to the manufacturers' instructions (Qiagen). The questionable $400 \mathrm{bp}$ amplicons obtained from the BAM degenerate PCR primers, were sequenced utilizing Amersham Biosciences ET Terminator chemistry using an ABI 377 DNA sequencer (Amplicon Express).

\section{I6S rRNA sequencing}

DNA sequencing for the 16S rRNA segment was performed as described by Iversen et al. [41]. PCR amplification of the ribosomal RNA gene was performed by mixing $1 \mu \mathrm{l}$ of extracted DNA with a $49 \mu \mathrm{l}$ of PCR mixture containing the following: $1 \times$ GeneAmp PCR buffer, 5 units AmpliTaq Gold DNA polymerase (Applied Biosystems), $0.2 \mathrm{mM}$ dNTPs, $1.5 \mathrm{mM} \mathrm{MgCl}_{2}$ and 1 pmol from primers 
Table I: Oligonucleotide primer pairs and PCR running conditions used in this study

\begin{tabular}{|c|c|c|c|c|}
\hline Primer & Sequence $5^{\prime}$ to $3^{\prime}$ & Targeted site & Amplicon size (bp) & Reference \\
\hline SG-F & GGGTTGTCTGCGAAAGCGAA ${ }^{a}$ & ITS-G & 282 & Liu et al., [44] \\
\hline SG-R & GTCTTCGTGCTGCGAGTTTG & ITS-G \& ITS-IA & & \\
\hline SI-F & CAGGAGTTGAAGAGGTTTAACT' & ITS-IA & 251 & Liu et al., [44] \\
\hline SI-R & GTGCTGCGAGTTTGAGAGACTC & ITS-G \& ITS-IA & & \\
\hline Saka la & ACAGGGAGCAGCTTGCTGC ${ }^{c}$ & VIg & 952 & Hassan et al., [45] \\
\hline Saka $2 b$ & TCCCGCATCTCTGCAGGA & $\sqrt{ } 3^{h}$ & & \\
\hline Zpx F & GAAAGCGTATAAGCGCGATTC & $z p x$ & 94 & Kothary et al., [13] \\
\hline Zpx R & GTTCCAGAAGGCGTTCTGGT & & & \\
\hline BAMI22 & AWATCTATGACGCGCAGAACCGe & $z p x$ & 350 & Kothary et al., [13] \\
\hline BAMI23 & AAAATAGATAAGCCCGGCTTCG & & & \\
\hline EsgluAf & TGAAAGCAATCGACAAGAAGf & gluA & 1680 & Lehner et al., [3] \\
\hline EsgluAr & АСTCATTACСССТССТGATG & & & \\
\hline EsgluBf & TGAGTGAAGCACCGACGCAGf & gluB & 1720 & Lehner et al., [47] \\
\hline EsgluBr & GTTACGTCACAGGTTTTGAT & & & \\
\hline ESSF & GGATTTAACCGTGAACTTTTCCi & ompA & 469 & Nair and Venkitanarayanan [46] \\
\hline ESSR & CGCCAGCGATGTTAGAAGA & & & \\
\hline
\end{tabular}

a\&b Running conditions; $94^{\circ} \mathrm{C}$ for $10 \mathrm{~min} ; 30$ cycles of $94^{\circ} \mathrm{C}$ for $30 \mathrm{sec}$ each; $57^{\circ} \mathrm{C}$ for $\mathrm{I}$ min; $72^{\circ} \mathrm{C}$ for $\mathrm{I}$ min; a final extension period of 5 min at $72^{\circ} \mathrm{C}$.

C Running conditions; $95^{\circ} \mathrm{C}$ for $4 \mathrm{~min} ; 30$ cycles of $95^{\circ} \mathrm{C}$ for $60 \mathrm{sec}$ each; $50^{\circ} \mathrm{C}$ for $1 \mathrm{~min} ; 72^{\circ} \mathrm{C}$ for $90 \mathrm{sec}$; final extension period of 4 min at $72^{\circ} \mathrm{C}$. d\&e Running conditions; The hot start polymerase was activated by incubation for $15 \mathrm{~min}$ at $95^{\circ} \mathrm{C}$; followed by $35 \mathrm{cycles}$ of $\mathrm{I}$ min at $95^{\circ} \mathrm{C} ; 62^{\circ} \mathrm{C}$ for zpx primers $\left(50.5^{\circ} \mathrm{C}\right.$ was used for 8 isolates) or $50^{\circ} \mathrm{C}$ for BAM primers for $1 \mathrm{~min} ; 72^{\circ} \mathrm{C}$ for $1 \mathrm{~min}$; final extension of $10 \mathrm{~min}$ at $72^{\circ} \mathrm{C}$ for $\mathrm{zpx}$ and 7 min for BAM primers.

${ }^{f}$ Running conditions were as described by Lehner et al. [3,47]; The hot start polymerase was activated by incubation for 15 min at $95^{\circ} \mathrm{C}$; followed by 30 cycles of $30 \mathrm{~s}$ at $94^{\circ} \mathrm{C} ; 56^{\circ} \mathrm{C}(\mathrm{gluA})$ or $58^{\circ} \mathrm{C}$ (gluB) for $1 \mathrm{~min} ; 72^{\circ} \mathrm{C}$ for $1.5 \mathrm{~min}$; final extension period of $5 \mathrm{~min}$ at $72^{\circ} \mathrm{C}$. 8\&h: Variable regions of the $16 \mathrm{~S}$ rRNA gene.

i Running conditions: $94^{\circ} \mathrm{C}$ for $2 \mathrm{~min} ; 30$ cycles $94^{\circ} \mathrm{C}$ for $15 \mathrm{sec}$ each; $60^{\circ} \mathrm{C}$ for $15 \mathrm{sec} ; 72^{\circ} \mathrm{C}$ for $30 \mathrm{sec}$; final extension period of 5 min at $72^{\circ} \mathrm{C}$.

Table 2: Cronobacter spp. isolates and the Genbank accession numbers of their I6S rRNA sequences.

\begin{tabular}{|c|c|c|c|}
\hline Isolate number & GenBank accession number & Isolate number & GenBank accession number \\
\hline I46A_095P.seq & F]906897 & 175_095P. seq & F]906898 \\
\hline s20B.seq & F]906899 & 22_095P.seq & F] 906900 \\
\hline s32.seq & F]906901 & s44A.seq & F]906902 \\
\hline s44B.seq & F] 906903 & s52.seq & F] 906904 \\
\hline s77.seq & F]906905 & s93.seq & F) 906906 \\
\hline s95.seq & Fj906907 & s96.seq & Fj906908 \\
\hline sII2.seq & F]906909 & sl46B.seq & F]906910 \\
\hline sl48.seq & F]90691I & sl49.seq & F]906912 \\
\hline s154.seq & F]906913 & sl60A.seq & F]906914 \\
\hline sl60B.seq & F) 906915 & sI70.seq & F]906916 \\
\hline sl7I.seq & Fj906917 & sl72.seq & F]906918 \\
\hline sl73.seq & F]906919 & sl74.seq & F]906920 \\
\hline ss I76.seq & F) 906921 & sl78.seq & F] 906922 \\
\hline ss $183 . s e q$ & F) 906923 & sl84.seq & F]906924 \\
\hline s204.seq & FJ906925 & & \\
\hline
\end{tabular}


P0 (5'-AGA GTT TGA TCC TGG CTC AG-3') and P6 (5'GTA CGG CTA CCT TGT TAC GA-3'). PCR amplification was performed as follows: $10 \mathrm{~min}$ at $95^{\circ} \mathrm{C} ; 30$ cycles of 30 sec at $95^{\circ} \mathrm{C}, 30 \mathrm{sec}$ at $56^{\circ} \mathrm{C}, 2 \mathrm{~min}$ at $72^{\circ} \mathrm{C} ; 5 \mathrm{~min}$ at $72^{\circ} \mathrm{C}$. The amplified products were visualized on $1 \%$ agarose gels, and then they were cut out from the gel and purified using the Wizard SV Gel and PCR clean-up system (Promega). The purified amplified fragments were sequenced using the primers P6 (5'-GTA CGG CTA CCT TGT TAC GA-3'), 095P (5'-TAC GGC GTG GAC TAC CAG$\left.3^{\prime}\right)$ and the BigDye Termination Kit (Applied Biosystems). Full-length 16S rRNA gene sequences were aligned and compared with the DNA sequences deposited in the GenBank by Iversen et al. [41] using alignment tool MegAlign of the DNAStar program package.

\section{Submission of I6S rRNA gene sequences}

All the obtained 16S rRNA gene sequences were submitted to the GenBank. The accession numbers of these sequences are listed in Table 2.

\section{Results and Discussion}

This investigation addresses the isolation of Cronobacter spp. from a wide range of foods and environmental samples in an attempt to pinpoint their source. Because of the phenotypic differences among Cronobacter spp., it has been increasingly difficult to confirm the identity of isolates using only one method or one set of Cronobacter spp.-specific PCR primers $[33,48]$. Thus, this study also addresses the use of different chromogenic, biochemical, and molecular techniques for characterization and identification of Cronobacter spp. from foods and environmental samples.

Two hundred and thirty three samples including infant formulas, dry milk powder, infant foods, vegetables, fruits, traditional drinks, cereals, herbs, and environmental samples were tested for the presence of Cronobacter spp. Table 3 shows the categories of food and environmental samples analyzed for the presence of Cronobacter spp. in the study. Table 3 also indicates the percentages of Cronobacter spp. found in each food category, while Table 4 shows the description of foods, beverages and environmental samples which were positive for Cronobacter spp. Among the 76 samples of infant formula, infant food, milk powder and dairy non-milk food products, only one infant food sample was positive for Cronobacter spp. $(1.4 \%)$. The highest percentage of Cronobacter spp. isolates $(39 \%)$ was found in herbs and spices and totaled about $89.6 \%$ of the total isolates in this study. In addition, two isolates (18\%) were recovered from vacuum dust collected from house holds. It is worth mentioning, that none of the tested milk powder samples contained Cronobacter spp. These results are in accordance with those described by Iversen and Forsythe [49], and NazarowecWhite and Farber [4] who suggested that pasteurization treatment when used in the final treatment stage eliminates all pathogens from such products. In contrast, other foods and beverages contained the highest levels of Cronobacter spp. For instance, the four samples of a traditional herbal drink, (liquorice) contained Cronobacter spp. $(100 \%)$ while 11 out of 15 samples $(73.3 \%)$ of mixed spices contained Cronobacter spp. These results are in accordance with reported results by Forsythe [11] and Friedemann [31] which emphasized that the majority of Cronobacter spp. isolates are from plant sources irrespective of the world region of analysis. These results imply that plants possibly embody the major reservoir of the pathogen.

Whether the Cronobacter spp. contamination is occurring intrinsically, i.e., endophytically or through contact with

Table 3: Categories of food and environmental samples tested for the presence of Cronobacter spp. and the numbers and percentages of the confirmed Cronobacter spp. isolates

\begin{tabular}{lcccc}
\hline Origin of Sample & $\begin{array}{c}\text { Number of samples } \\
\text { analyzed }\end{array}$ & $\begin{array}{c}\text { Number of Cronobacter } \\
\text { spp. isolates }\end{array}$ & $\begin{array}{c}\text { \% of total samples in the } \\
\text { category }\end{array}$ & $\begin{array}{c}\text { \% of total isolates } \\
\text { Infant formula and milk }\end{array}$ \\
$\begin{array}{l}\text { powder } \\
\text { Cereals and Cereal } \\
\text { products }\end{array}$ & 69 & 1 & 0 & 3.4 \\
$\begin{array}{l}\text { Herbs and Spices } \\
\text { Miscellaneous food }\end{array}$ & 67 & 0 & 39 & 0 \\
$\begin{array}{l}\text { products } \\
\text { Beverages }\end{array}$ & 34 & 0 & 0 & 0 \\
$\begin{array}{l}\text { Dairy products other than } \\
\text { milk powder }\end{array}$ & 7 & 0 & 0 & 0 \\
$\begin{array}{l}\text { Vegetables and fruits } \\
\text { Environmental samples }\end{array}$ & 7 & 0 & 0 & 0 \\
\hline Total & 6 & 0 & 18.2 & 0 \\
\hline
\end{tabular}


Table 4: Detailed description and percentages of food, beverages and environmental samples which contained Cronobacter spp. isolates

\begin{tabular}{|c|c|c|c|}
\hline Sample Type & $\begin{array}{c}\text { Number of Samples of a } \\
\text { category }\end{array}$ & $\begin{array}{c}\text { Number of Cronobacter spp. } \\
\text { isolates }\end{array}$ & $\begin{array}{l}\text { \% of samples positive for } \\
\text { Cronobacter spp. }\end{array}$ \\
\hline \multicolumn{4}{|l|}{$\begin{array}{l}\text { Infant Formula and infant } \\
\text { Foods }\end{array}$} \\
\hline Infant foods & 40 & 1 & 2.5 \\
\hline \multicolumn{4}{|l|}{ Herbs and Herbal Beverages } \\
\hline Liquorice & 4 & 4 & 100 \\
\hline Thyme & 4 & 1 & 25 \\
\hline Anise & 8 & 4 & 50 \\
\hline Chamomile & 8 & 2 & 25 \\
\hline Fennel & 6 & 3 & 50 \\
\hline Sage & 2 & 1 & 50 \\
\hline Mixed Spices & 15 & 11 & 73.3 \\
\hline Environmental (vacuum dust) & 6 & 2 & 33.3 \\
\hline Total & 93 & 29 & 31.2 \\
\hline
\end{tabular}

water, rodents, soil or insects during the primary preparation of these food products $[11,18]$ has yet to be determined. Apparently, Cronobacter spp. survives the primary processing, shipping and exportation procedures well due to its thermo/dry/osmotic tolerant nature. Therefore, our results along with those previously reported, further confirm that Cronobacter spp. are ubiquitous microbes found in a wide array of foods and beverages including infant formula. However, due to its thermotolerant [7] and osmotolerant nature [6], the organism survives in dry foods, herbs, spices and the general manufacturing environment and appears to contaminate infant formula and infant foods at certain stages during the processing, particularly after sterilization i.e., during a vitamin or supplement fortification steps.

Nevertheless, previous studies by Shaker at al. [22] and Mullane et al. [16] reported conflicting results, in that, the former study reported a lack of Cronobacter spp. from 40 samples taken from an infant food factory, while the latter study lasting 12 months, isolated approximately 80 Cronobacter spp. isolates from infant food factories. Of these isolates, $72.5 \%$ were isolated from the factory environment. These findings provide evidence for the role of the environment in the contamination of the final product. It is interesting to note that in the current study, two Cronobacter spp. isolates were found in house-hold vacuum dust. This further supports the hypothesis of the role played by environmental contamination in factories or during the formula preparation in nurseries or the homes [31]. The high association of this pathogen with herbs and spices suggests that extra precautions should be taken when home remedies containing herbs or herbal beverages are given to infants to alleviate gastrointestinal discomfort. It should be mentioned that our findings reflect possibly an underestimation of Cronobacter spp. which might be associated with the foods (other than infant formula, infant food and milk powder) and environmental samples analyzed by the FDA BAM method because of only working up "yellow-pigmented colonies". However, these findings also support the need of isolation schemes that incorporate multiple chromogenic media.

All isolates were evaluated for phenotypic traits using biochemical profiling test (API 20E), and chromogenic ( $\alpha$ MUG, DFI and EsPM) assays while evaluated for genotypic traits using PCR analyses (eight sets of primers) and $16 \mathrm{~S}$ rRNA sequencing. According to the initial screening, 56 isolates showed yellow colonies on TSA, typical for Cronobacter spp. However, when the isolates were subjected to API 20E biochemical profiling, only 42 isolates $(75 \%)$ were identified as E. sakazakii with high identity scores (80-99\% E. sakazakii) (Tables 5 and 6) and thus were considered presumptive Cronobacter spp. API $20 \mathrm{E}$ biochemical profiling can thus be considered a first screening or presumptive identification method for Cronobacter spp., after which the isolates should undergo further diagnostic analyses. To that end, the presumptive isolates were grown on chromogenic media ( $\alpha$-MUG, DFI and EsPM) as a second step of identification. Results showed that none of the three chromogenic media was $100 \%$ reliable (Table 7 ) for confirming the identity of Cronobacter spp. isolates. However, it is worth mentioning that both chromogenic $\alpha$-MUG and DFI gave no false negatives and only few false positives ( 5 and 3 for $\alpha$-MUG and DFI respectively) compared to the EsPM media which missed 3 positives and identified 7 non-Cronobacter spp. isolates as Cronobacter spp. These results proved that DFI followed by $\alpha$-MUG are more reliable than the EsPM Media as intermediate confirmation steps. Among the non-Cronobacter spp. isolates, two isolates did not grow on DFI media although they tested positive for $\alpha$-glucosi- 
Table 5: Confirmed isolates of Cronobacter spp. by biochemical testing (API 20E), chromogenic (a-MUG, DFI and EsPM), eight sets of Cronobacter spp. specific primers (a-GluA, a-GluB, SG, SI, Saka, OmpA, zpx and BAM) and I6S rRNA sequence analysis.

\begin{tabular}{|c|c|c|c|c|c|c|c|c|c|c|c|c|c|c|}
\hline \multicolumn{2}{|c|}{ Isolate } & \multirow[b]{2}{*}{ API 20E } & \multirow[b]{2}{*}{$\alpha$-MUG } & \multirow[b]{2}{*}{ DFI } & \multirow[b]{2}{*}{ EsPM\$ } & \multicolumn{8}{|c|}{ PCR Primers } & \multirow[b]{2}{*}{ I6S rRNA } \\
\hline ID & Source & & & & & $\alpha$-GluA & $\alpha$-GluB & SG & SI & Saka & OmpA & zpx & $\begin{array}{c}\text { BAM } \\
\mathbf{n}\end{array}$ & \\
\hline 51329 & ATCC & + & + & + & BB & + & ND§ & + & + & + & + & + & $+*$ & Crono. ${ }^{t}$ \\
\hline 29544 & ATCC & + & + & + & BB & + & + & ND & ND & ND & ND & + & + & Crono. \\
\hline Jor32 & Infant food & + & + & + & BB & + & ND & + & + & + & + & + & + & Crono. \\
\hline Jor20B & Spices & + & + & + & $\mathrm{BB}$ & + & ND & + & + & + & + & + & + & Crono. \\
\hline Jor22 & Chamomile & + & + & + & $\mathrm{BB}$ & + & ND & + & + & + & + & + & + & Crono. \\
\hline Jor44A & Spices & + & + & + & $\mathrm{BB}$ & + & ND & + & + & + & + & - & + & Crono. \\
\hline Jor44B & Spices & + & + & + & $\mathrm{BB}$ & + & ND & + & + & + & + & + & + & Crono. \\
\hline Jor77 & Anise & + & + & + & BB & + & ND & + & + & + & + & + & $+^{*}$ & Crono. \\
\hline Jor93 & spices & + & + & + & $\mathrm{BB}$ & + & ND & + & + & + & + & - & + & Crono. \\
\hline Jor95 & Anise & + & + & + & $\mathrm{BB}$ & + & ND & + & + & + & + & + & $+*$ & Crono. \\
\hline Jor96 & Fennel & + & + & + & BB & + & ND & + & + & + & + & - & + & Crono. \\
\hline Jor II2 & Liquorice & + & + & + & $\mathrm{BB}$ & + & ND & + & + & + & + & + & $+*$ & Crono. \\
\hline Jor I46B & Liquorice & + & + & + & $\mathrm{BB}$ & + & ND & + & + & + & + & - & + & Crono. \\
\hline Jor 148 & Spices & + & + & + & $\mathrm{BB}$ & + & ND & + & + & + & + & + & + & Crono. \\
\hline Jor 149 & Anise & + & + & + & $\mathrm{BB}$ & - & - & + & + & + & + & + & $+*$ & Crono. \\
\hline Jor 154 & Spices & + & + & + & $\mathrm{BB}$ & - & + & + & - & + & + & + & + & Crono. \\
\hline Jor $160 \mathrm{~A}$ & Vac dust $¥$ & + & + & + & $\mathrm{BB}$ & + & ND & + & + & + & + & + & + & Crono. \\
\hline Jor 160B & Vac dust ${ }^{*}$ & + & + & + & BB & + & ND & + & + & + & + & - & + & Crono. \\
\hline Jor I7I & Fennel & + & + & + & $\mathrm{BB}$ & + & ND & + & + & + & + & + & $+*$ & Crono. \\
\hline Jor I72 & Spices & + & + & + & $\mathrm{BB}$ & + & ND & + & + & - & + & + & + & Crono. \\
\hline Jor 173 & Spices & + & + & + & $\mathrm{BB}$ & + & ND & + & + & + & + & + & + & Crono. \\
\hline Jor I74 & Anise & + & + & + & BB & + & ND & + & + & + & + & - & $+*$ & Crono. \\
\hline Jor I75 & Spices & + & + & + & $\mathrm{BB}$ & - & - & + & + & + & + & + & + & Crono. \\
\hline Jor 176 & Thyme & + & + & + & $\mathrm{BB}$ & + & ND & + & + & - & - & - & $+*$ & Crono. \\
\hline Jor 183 & Spices & + & + & + & BB & + & ND & + & + & + & + & + & + & Crono. \\
\hline Jor204 & Liquorice & + & + & + & $\mathrm{BB}$ & + & - & + & + & + & + & + & + & Crono. \\
\hline Jor I46A & Liquorice & + & + & + & $\mathrm{BB}$ & + & ND & + & + & + & + & + & + & Crono. \\
\hline Jor 178 & Chamomile & + & + & + & $\mathrm{BB}$ & + & ND & + & + & + & + & - & + & Crono. \\
\hline Jor52 & Sage & + & + & + & $\mathrm{Y} / \mathrm{Gr}$ & - & ND & - & - & - & - & - & $-* \#$ & Crono. \\
\hline Jor I 70 & Fennel & + & + & + & Gray & - & ND & - & - & - & + & - & - & Crono. \\
\hline Jor 184 & Spices & + & + & + & $\mathrm{Y} / \mathrm{Gr}$ & - & ND & + & + & + & + & + & - & Crono. \\
\hline Total + & & 31 & 31 & 31 & 28 & 25 & 2 & 28 & 27 & 26 & 28 & 21 & 28 & \\
\hline
\end{tabular}

$\$$ On EsPM, colonies were blue black (BB) in chromogenic reaction color within $24 \mathrm{~h}$ at $37^{\circ} \mathrm{C}$. $\mathbf{n T h e}$ PCR conditions for BAM primers as described in Table I were used for amplification of both regions of the zpx gene as described by Kothary et al. [I3]. Analysis of the Cronobacter and nonCronobacter strains was performed in a similar fashion. $¥$ Vacuum dust. ND\$: not determined. * Multiple bands. *\#, PCR product was approximately (400 bp) and sequence was found not to be zpx. \#Colonies were blue black (BB) after three days at $37^{\circ} \mathrm{C}$. $£$ Crono; Cronobacter spp.

dase activity on $\alpha$-MUG. These isolates may be sensitive to the sodium deoxycholate, an ingredient added to the medium to suppress gram positive bacteria [1].

Surprisingly, the identities of 13 of the isolates (Table 6) identified as E. sakazakii by API $20 \mathrm{E}$ analysis were not confirmed by the other methods used including chromogenic, PCR and the final 16S rRNA sequence analysis. There have been several comparative studies performed to determine the usefulness of biochemical test strips and chromogenic as a diagnostic tool for the identification of Cronobacter spp. However, these studies have given conflicting results $[48,50,51]$ highlighting the need for other methods of confirmation such as molecular and the DNA sequencing methods.
PCR analysis using eight different sets of primers from six separate studies [3,13,44-47] was used to help ascertain the identity of all the presumptive isolates. Standard ATCC strains (51329 and 29544) were used as a positive control. Although eight sets of PCR primers from six different studies each claiming high sensitivity and specificity for detection and confirmation of Cronobacter spp. were used to ascertain the identity of the isolates in this study, only 13 isolates in addition to the ATCC (51329) strain were positive with all the primers (Table 5). The other 16 isolates did not give the predicted PCR product with at least one set of primers although they were identified as Cronobacter spp. by other biochemical and/or chromogenic methods. When the isolates were tested with the PCR primer sets, DNA was not amplified in a high 
Table 6: Presumptive Cronobacter spp. as appeared through testing the isolates by biochemical profiling (API20E), chromogenic (a-MUG, DFI, EsPM) and eight sets of Cronobacter spp- specific primers (a-gluA, a-gluB, SG, SI, Saka, OmpA, zpx and BAM), while confirmed as non-Cronobacter spp. by I6S rRNA sequence analysis.

\begin{tabular}{|c|c|c|c|c|c|c|c|c|c|c|c|c|c|c|}
\hline \multicolumn{2}{|c|}{ Isolate } & \multirow[b]{2}{*}{ API 20E } & \multirow[b]{2}{*}{$\alpha$-MUG } & \multirow[b]{2}{*}{ DFI } & \multirow[b]{2}{*}{ EsP M } & \multicolumn{8}{|c|}{ PCR Primers } & \multirow[b]{2}{*}{ I 6S rRNA } \\
\hline ID & Source & & & & & $\alpha$-GluA & $\alpha$-GluB & SG & SI & Saka & OmpA & zpx & $\underset{\mathbf{n}}{\text { BAM }}$ & \\
\hline Jor20A & Spices & + & - & - & Clear & - & ND & + & + & - & - & + & - & N.Crono \\
\hline Jor27 & Chamomile & + & - & - & Y\& & - & ND & + & + & - & - & + & - & N.Crono \\
\hline Jor45 & Sugar & + & - & - & Gray & - & ND & + & + & - & - & + & - & N.Crono \\
\hline Jor II $5 \mathrm{~A}$ & Dates & + & + & NG@ & $\mathrm{Y} / \mathrm{Gr}$ & - & ND & - & - & - & - & + & - & N.Crono \\
\hline Jor II5B & Dates & + & + & NG@ & $\mathrm{Y} / \mathrm{Gr}$ & - & ND & - & - & - & - & + & $-* \#$ & N.Crono \\
\hline Jor5I & Dry dairy & + & + & + & Y/Gr\#\# & - & ND & + & + & - & - & + & $-\#$ & N.Crono \\
\hline Jor I53B & Semolina & + & + & + & BB & - & - & + & + & - & - & + & - & N.Crono \\
\hline Jor26 & Rice & + & - & - & $\mathrm{BB}$ & - & - & + & + & - & - & + & + & N.Crono \\
\hline Jor 100 & Semolina & + & - & - & $\mathrm{BB}$ & + & ND & + & + & - & - & + & + & N.Crono \\
\hline Jor 103 & Spices & + & - & - & $\mathrm{BB}$ & + & ND & + & + & - & - & + & + & N.Crono \\
\hline Jor 109 & Grapes & + & - & - & $\mathrm{BB}$ & + & ND & + & + & - & - & + & + & N.Crono \\
\hline Jor 168 & Spices & + & - & - & BB & - & - & + & + & - & - & + & + & N.Crono \\
\hline Jor I5I & Fennel & + & + & + & BB & - & + & - & - & - & - & + & + & N.Crono \\
\hline Total + & & 13 & 5 & 3 & 7 & 3 & I & 10 & 10 & 0 & 0 & 13 & 6 & \\
\hline
\end{tabular}

nThe PCR conditions for BAM primers as described in Table I were used for amplification of both regions of the zpx gene as described by Kothary et al. [13]. * multiple bands. *\#, PCR product was approximately (400 bp) and sequence was found not to be zpx. \& Y, yellow colony chromogenic reaction color, $24 \mathrm{~h}$ at $37^{\circ} \mathrm{C}$. Gr, green colony chromogenic reaction color, $24 \mathrm{~h}$ at $37^{\circ} \mathrm{C}$. @ NG; no growth on DFI at $37^{\circ} \mathrm{C}$. \#Colonies were blue black (BB) after three days at $37^{\circ} \mathrm{C}$. N. Corono; None Cronobacter spp.

number of strains especially when tested with the $z p x$ ( 94 bp product) and gluB detecting only $21 / 31$ and $2 / 5$ respectively. The other sets of primers where more reliable detecting 25/31,26/30,27/30, 28/31 for gluA, Saka, SI and BAM primer sets respectively while both OmpA and SG appeared to be most reliable among the tested primer sets detecting 28/30 isolates.

These observations suggest that there may be some sequence variability in the genes of these strains of Crono- bacter spp. that were not observed by the reporting authors $[3,13,47]$.

In addition, it is noteworthy to mention that strains Jor149, Jor154, Jor175, Jor 52, Jor170, Jor184, Jor51, Jor153B and Jor 151 gave conflicting $\alpha$-glucosidase activity (on $\alpha$-MUG or DFI) that did not correspond with PCR results for the presence of gluA. All these strains had expressed $\alpha$-glucosidase activity on both $\alpha$-MUG and DFI, but were negative by PCR for the presence of gluA. Because

Table 7: Summary of the performance of the biochemical, chromogenic and PCR methods for Cronobacter spp. identity confirmation.

\begin{tabular}{|c|c|c|c|}
\hline Test Method & Number of confirmed isolates & Number of false positives & Number of false negatives \\
\hline API 20E & 42 & 13 & - \\
\hline$\alpha$-MUG & 34 & 5 & - \\
\hline DFI & 32 & 3 & - \\
\hline EsPM & 33 & 7 & 3 \\
\hline Glu A PCR primers & 26 & 3 & 6 \\
\hline Glu B*PCR primers & 3 & 1 & 3 \\
\hline SG PCR primers & 36 & 10 & 2 \\
\hline SI PCR primers & 36 & 10 & 3 \\
\hline Ska PCR primers & 25 & - & 4 \\
\hline OmpA PCR primers & 27 & - & 2 \\
\hline Zpx 94 bp PCR primers & 32 & 13 & 10 \\
\hline Zpx 350 bp PCR primers & 32 & 6 & 3 \\
\hline
\end{tabular}

*: Only 9 samples were tested using these primers 
of these results we tested some of the gluA PCR negative strains with primers that targeted gluB by using primers, parameters and PCR reaction conditions described by Lehner et al [47]. The PCR results showed that these primers did not detect gluB in the tested strains (except strains Jor 151 and Jor 154), suggesting that the $\alpha$-glucosidase activity observed was due to the expression of a second uncharacterized $\alpha$-glucosidase gene or that these strains possessed gluA and gluB sequence variants that were not recognized by these primers under the reported conditions. These results are in contrast with results from strains Jor151 and Jor154 which also had $\alpha$-glucosidase activity, but PCR results showed that gluB was present and not gluA, suggesting that the glucosidase activity of these strains was due solely to the expression of $g l u B$. These results are also opposite to that for strain Jor204 which by PCR showed that its $\alpha$-glucosidase activity was due to gluA and not gluB. Lastly, Strains Jor 26, Jor 100, Jor 103, Jor 109 , and Jor168 expressed no $\alpha$-glucosidase activity during growth on $\alpha$-MUG or DFI yet produced typical chromogenic reactions on EsPM suggesting that these strain's chromogenic activity on the latter medium was due to cellobiosidase activity or due to expression of sequence variants of $\alpha$-glucosidase genes. The later outcome is the most probable reason for these conflicting results since all of these strains showed either $\alpha$-glucosidase activity or palatinase activity by VITEK GN analysis (data not shown). These results support the finding by Iversen and Forsythe [2] that the chromogenic reaction of strains grown on DFI medium can be misleading and that the new modified formulation of DFIA put forth by Iversen et al [48] should alleviate the problems of strains producing atypical reactions on this medium.

Table 6, depicts the characterization of the non Cronobacter spp. isolates. All the isolates were identified as putative Cronobacter spp. with API 20E biochemical profiling. However, chromogenic media ( $\alpha$-MUG and DFI) were negative for 8 isolates (Jor20A, Jor27, Jor45, Jor26 Jor100, Jor103, Jor109, and Jor168) while positive for the other 5 isolates (Jor115A, Jor115B, Jor51, Jor151 and Jor153B) and EsPM was negative for 6 samples and positive for 7 samples. These conflicting results stressed the inability of chromogenic methods to provide a reliable test for confirming the identity of the Cronobacter spp. isolates. Table 7 summarized the results obtained by the different methods used for the identification and confirmation of isolates and clearly highlights the inability of any single method to be used as a final confirmation method. Due to the above conflicting results, a final confirmation step was undertaken by sequencing the 16S rRNA gene of the isolates. As a result of final confirmation method only 29 isolates (Table 5) were confirmed as Cronobacter spp. while the other 13 isolates (Table 6) were confirmed as non-Cronobacter spp.
The variation in the above results reflects the genetic heterogeneity among the Cronobacter spp. isolates and/or a high degree of similarity between Cronobacter spp. and some other closely related members of Enterobacteriaceae that tested positive with some of the confirmation tests as depicted in Table 6 . This conclusion is supported by very recent reports by Iversen et al., [41,42] and Barron et al., [33] who have proposed a new scheme for classifying $E$. sakazakii isolates based on f-AFLP, DNA-DNA hybridization, riboprinting and full-length, 16S rRNA gene sequences and phenotypic characteristics.

\section{Conclusion}

Cronobacter spp. are ubiquitous in nature, and herbs and spices appear to be one possible natural reservoir and thus special care should be taken while preparing infant foods or formulas in order to avoid cross-contamination from these sources. Finally, the Cronobacter spp. are very diverse as indicated by the variation in the confirmation results both phenotypic and genotypic. Among the methods, the $\alpha-M U G$ and DFI could be used for putative identification of Cronobacter spp. followed by the SG, OmpA and BAM PCR analysis. However, the 16S rRNA sequence analysis should be used as a final confirmation step and is pivotal for eliminating the doubts shed by the inability of other methods for identification and confirmation of the identity of the Cronobacter spp. Therefore, a combination of confirmation methods might be necessary to completely eliminate false positives and false negatives.

\section{Authors' contributions}

ZWJ wrote the proposal for the fund, supervised all the experimental work and wrote the manuscript. QOA participated in the PCR experiments, 16S rDNA sequencing and alignment, and manuscript writing. IMS participated in supervising the work at the laboratory. NAS isolated the Cronobacter spp. isolates from foods. AMR participated in PCR experiments and chromogenic identification of the pathogens. All authors read and approved the final manuscript.

\section{Acknowledgements}

The authors would like to acknowledge Ben D. Tall, Mahendra, H. Kothary and Venugopal Sathyamoorthy from US FDA for their valuable assistance for identifying the isolates and for their constructive comments on the manuscript. This research was funded by the Deanship of Research at the Jordan University of Science and Technology.

\section{References}

I. Iversen C, Druggan $P$, Forsythe SJ: A selective differential medium for Enterobacter sakazakii; a preliminary study. Int J Food Microbiol 2004, 96:133-139.

2. Iversen C, Forsythe SJ: Comparison of media for the isolation of Enterobacter sakazakii. Appl Environ Microbiol 2007, 73:48-52.

3. Lehner A, Nitzsche S, Breeuwer P, Diep B, Thelen K, Stephan R: Comparison of two chromogenic media and evaluation of two molecular based identification systems for Enterobacter sakazakii detection. BMC Microbiol 2006, 6:I5. 
4. Nazarowec-White M, Farber JM: Enterobacter sakazakii a review. Int J Food Microbiol 1997, 34:103-I I3.

5. Barron JC, Forsythe SJ: Dry stress and survival time of Enterobacter sakazakii and other Enterobacteriaceae in dehydrated powdered infant formula. J Food Prot 2007, 70:21II-2117.

6. Breeuwer P, Lardeau A, Peterz M, Joosten HM: Desiccation and heat tolerance of Enterobacter sakazakii. J Appl Microbiol 2003 , 95:967-973.

7. Nazarowec-White M, Farber JM: Thermal resistance of Enterobacter sakazakii in reconstituted dried-infant formula. Lett Appl Microbiol 1997, 95:967-973.

8. Gurtler JB, Beuchat LR: Survival of Enterobacter sakazakii in powdered infant formula as affected by composition, water activity, and temperature. J Food Prot 2007, 70:1579-1586.

9. $\mathrm{Kim} \mathrm{SH}$, Park $\mathrm{JH}$ : Thermal resistance and inactivation of Enterobacter sakazakii isolates during rehydration of powdered infant formula. J Microbial Biotech 2007, 17:364-368.

10. Corti G, Panunzi I, Losco M, Buzzi R: Post-surgical osteomyelitis caused by Enterobacter sakazakii in a healthy young man. J Chemotherapy 2007, 19:94-94.

II. Forsythe S): Enterobacter sakazakii and other bacteria in powdered infant milk formula. J Matern Child Nutr 2005, I:44-50.

12. Gallagher PG: Enterobacter bacteremia in pediatric patients. Rev Infect Dis 1990, I 2:808-8I2.

13. Kothary MH, McCardell BA, Frazar CD, Deer D, Tall BD: Characterization of the zinc-containing metalloprotease encoded by zpx and development of a species-specific detection method for Enterobacter sakazakii. Appl Environ Microbiol 2007 73:4|42-4|5|.

14. Lehner A, Stephan R: Microbiological, epidemiological, and food safety aspects of Enterobacter sakazakii. J Food Prot 2004, 67:2850-2857.

15. Mullane NR, Iverson C, Healy B, Walsh C, Whyte P, Wall PG, Quinn $T$, Fanning S: Enterobacter sakazakii an emerging bacteria pathogen with implications for infant health. Minerva Pediatrica 2007, 59:137-148.

16. Mullane NR, Whyte P, Wall PG, Quinn T, Fanning S: Application of pulse field gel electrophoresis to characterize and trace the prevalence of Enterobacter sakazakii in an infant formula processing facility. Int J Food Microbiol 2007, I | 6:73-8 I.

17. Muytjens HL, Zanen HC, Sonderkamp HJ, Kollee LA, Wachsmuth IK Farmer J]: Analysis of eight cases of neonatal meningitis and sepsis due to Enterobacter sakazakii. J Clin Microbiol 1983, 18:115-120.

18. Gurtler JB, Kornacki JL, Beuchat L: Enterobacter sakazakii: A coliform of increased concern to infant health. Int J Food Microbiol 2005, 104:I-34

19. Farmer J], Asbury MA, Hickman FW, Brenner DJ: The Enterobacteriaceae study group. Enterobacter sakazakii: a newspecies of Enterobacteriaceae" isolated from clinical specimens. Int J Syst Bacteriol 1980, 30:569-584.

20. Muytjens HL, Roelofs-Willemse H, Jaspar GHJ: Quality of powdered substitutes for breast milk with regard to members of the family Enterobacteriaceae. J Clin Microbiol 1988, 26:743-746.

21. Restaino L, Frampton EW, Lionberg WC, Becker RJ: A chromogenic plating medium for the isolation and identification of Enterobacter sakazakii from foods, food ingredients, and environmental sources. J Food Prot 2006, 69:315-322.

22. Shaker R, Osaili T, Al-Omary W, Jaradat Z, Al-Zuby M: Isolation of Enterobacter sakazakii and other Enterobacter sp. from food and food production environments. Food Control 2007, I 8: $124 \mid-1245$.

23. Bar-Oz B, Preminger A, Peleg O, Block C, Arad I: Enterobacter sakazakii infection in the newborn. Acta Paediatr 200I, 90:356-358

24. Block C, Peleg O, Minster N, Bar-Oz B, Simhon A, Arad I, Shapiro M: Cluster of neonatal infections in Jerusalem due to unusual biochemical variant of Enterobacter sakazakii. Eur J Clin Microbiol Infect Dis 2002, 21:613-616.

25. Clark NC, Hill BC, O'Hara CM, Steingrimsson O, Cooksey RC: Epidemiologic typing of Enterobacter sakazakii in two neonatal nosocomial outbreaks. Diagn Microbiol Infect Dis 1990, 1 3:467-472

26. Muytjens H, Kollee LA: Enterobacter sakazakii meningitis in neonates: causative role of formula? Pediatr Infect Dis J 1990 , 9:9372-9373.
27. Cottyn B, Regalado E, Lanoot B, de Cleene M, Mew TM, Swings ]: Bacterial populations associated with rice seed in the tropical environment. Phytopathology 200 I, 9 I:282-292.

28. Gassem MA: A microbiological study of Sobia: a fermented beverage in the Western province of Saudi Arabia. J Appl Microbiol 2002, 18: 173-177.

29. Iversen C, Forsythe SJ: Risk profile of Enterobacter sakazakii, an emergent pathogen associated with infant milk formula. Trends 2003, 14:443-454.

30. Soriano JM, Rico H, Molto JC, Manes J: Incidence of microbial flora in lettuce, meat and Spanish potato omelet from restaurants. Food Microbiol 2001, 18:159-163.

31. Friedemann M: Enterobacter sakazakii in food and beverages (other than infant formula and milk powder). Int J Food Microbiol 2007, I I 6: I- I0

32. Lai KK: Enterobacter sakazakii infections among neonates, infants, children and adults. Case reports and a review of the literature. Medicine 200I, 80:II3-122.

33. Barron C], Hurrell E, Townsend S, Cheetham P, Loc-Carrillo C, Fayet $O$, Prere MF, Forsythe SJ: Genotypic and phenotypic analysis of Enterobacter sakazakii strains from an outbreak resulting in fatalities in a neonatal intensive care unit in France. J Clin Microbiol 2007, 45:3979-3985.

34. Assadi MM, Mathur RP: Application of an HPLC system in the analysis of biodegraded crude oil compounds. LiQ Chromatogr 1991, 14:3623-3629.

35. Espeland EM, Wetzel RG: Complexation, stabilization and UV photolysis of extracellular and surface-bound glucosidase and alkaline phosphatase: implications for biofilm microbiota. Microbial Ecol 200I, 42:572-585.

36. Gakuya FM, Kyule MN, Gathura PB, Kariuki S: Antimicrobial resistance of bacterial organisms isolated from rats. $E A f r$ Med J 200I, 78:646-649.

37. Kuzina LV, Peloquin J], Vacek DC, Miller TA: Isolation and identification of bacteria associated with adult laboratory Mexican fruit flies, Anastrepha ludens (Diptera: Tephritidae). Curr Microbiol 2001, 42:290-294.

38. Mramba F, Broce A, Zurek L: Isolation of Enterobacter sakazakii from stable flies, stomoxys calcitrans L. (Diptera: Muscidae). J Food Prot 2006, 69:67|-673.

39. Neelam M, Nawaz Z, Riazuddin S: Hydrocarbon biodegradation biochemical characterization of bacteria isolated from local soils. Pakistan J Sci Ind Res 1987, 30:382-385.

40. Iversen C, Waddington M, Farmer JJ, Forsythe SJ: The biochemical differentiation of Enterobacter sakazakii genotypes. $B M C$ Microbiol 2006, 6:94.

4I. Iversen C, Lehner A, Mullane N, Bidlas E, Cleenwerck I, Marugg J, Fanning S, Stephan R, Joosten $\mathrm{H}$ : The taxonomy of Enterobacter sakazakii: proposal of a new genus comb. nov. Cronobacter sakazakii subsp. sakazakii, comb. nov., Cronobacter sakazaki subsp. malonaticus subsp. nov., Cronobacter turicensis sp. nov., Cronobacter muytjensii sp. nov., Cronobacter dublinensis sp. nov. and Cronobacter genomospecies I. BMC Evol Biol 2007, 7:64.

42. Iversen C, Mullane M, McCardell B, Tall BD, Lehner A, Fanning S, Stephan $\mathrm{R}$, Joosten $\mathrm{H}$ : Cronobacter gen. nov., a new genus to accommodate the biogroups of Enterobacter sakazakii, and proposal of Cronobacter sakazakii gen. nov., comb. nov., $C$. malonaticus sp. nov., C. turicensis, sp. nov., C. muytjensii sp. nov., $C$. dublinensis sp. nov., Cronobacter genomospecies I, and of three subspecies. $C$. dublinensis sp. nov. subsp. dublinensis subsp. nov. $C$. dublinensis sp. nov. subsp. lausannensis subsp. nov., and $C$. dublinensis sp. nov. subsp. lactaridi subsp. nov. Int J Sys Evol Microbiol 2008, 58: | 442- I 447.

43. FDA: Isolation and enumeration of Enterobacter sakazakii from dehydrated powdered infant formula. 2002 [http:// www.FDA.gov/Food/ScienceResearch/LaboratoryMethods/ ucm I I 4665.htm]. (serial online)

44. Liu Y, Gao Q, Zhang X, Hou Y, Yang J, Huang X: PCR and oligonucleotide array for detection of Enterobacter sakazakii in infant formula. Mol Cell Probe 2006, 20: I I-17.

45. Hassan AA, Akineden O, Kress C, Estuningsih S, Schneider E, Usleber E: Characterization of the gene encoding the I6S rRNA of Enterobacter sakazakii and development of a species-specific PCR method. Int J Food Microbiol 2007, | | 6:2 | 4-220. 
46. Nair MKM, Venkitanarayanan KS: Cloning and Sequencing of the ompA Gene of Enterobacter sakazakii and development of an ompA-targeted PCR for rapid detection of Enterobacter sakazakii in infant formula. Appl Environ Microbiol 2006, 72:2539-2546.

47. Lehner A, Riedel K, Rattei T, Ruepp A, Frishman D, Breeuwer P, Diep B, Eberl L, Stephan R: Molecular characterization of the $\alpha$-glucosidase activity in Enterobacter sakazakii reveals the presence of a putative gene cluster for palatinose metabolism. Syst Appl Microbiol 2006, 29:609-625.

48. Iversen C, Lehner A, Mullane N, Marugg J, Fanning S, Stephan R, Joosten H: Identification of "Cronobacter " spp. (Enterobacter sakazakii). J Clin Microbiol 2007, 45:38I4-38I6.

49. Iversen C, Forsythe S: Isolation of Enterobacter sakazakii and other Enterobacteriaceae from powdered infant formula milk and related products. Food Microbiol 2004, 21:77I-777.

50. Drudy D, Rourke MO, Murphy M, Mullane NR, O'Maony R, Kelly L, Fisher M, Sanjaq S, Shannon P, Wall P, O'Mahony M, Whyte P, Fanning $\mathrm{S}$ : Characterization of a collection of Enterobacter sakazakii isolates from environmental and food sources. Int J Food Microbiol 2006, I I 0:127-134.

5I. Fanjat N, Leclercq A, Joosten H, Robichon D: Comparison of the Phenotyping Methods ID32 and VITEK 2 Compact GN with 16S rDNA Gene Sequencing for the Identification of Enterobacter sakazakii. J Clin Microbiol 2007, 45:2048-2050.

Publish with Bio Med Central and every scientist can read your work free of charge

"BioMed Central will be the most significant development for disseminating the results of biomedical research in our lifetime. "

Sir Paul Nurse, Cancer Research UK

Your research papers will be:

- available free of charge to the entire biomedical community

- peer reviewed and published immediately upon acceptance

- cited in PubMed and archived on PubMed Central

- yours - you keep the copyright

Submit your manuscript here:

http://www.biomedcentral.com/info/publishing_adv.asp
BiolMedcentral 